The Quarterly Journal of Austrian Economics

Volume 22 | No.3 | 336-356 | Fall 2019

WWW.QJAE.ORG

\title{
Negative Inflation Targeting: A Proposal of a Non-Distortionary Monetary Policy
}

\author{
TOMÁš FrÖMMEL*
}

JEL Classification: B53, E31, E32, E52, E58

AвstRACT: This paper aims to propose a non-distortionary monetary policy objective consistent with the Austrian business cycle theory. Since the price level should fall in the growing economy in the Hayekian framework, introduction of a negative inflation target combined with the Taylor rule is suggested as a non-distortionary monetary policy. To keep the money stream stable, the optimal inflation target would be equal to the opposite of the growth rate of the economy. Such policy should lead to the smoothing of the business cycle path since monetary policy could be less activist compared to the current state of the positive inflation target. Possible criticisms of this suggestion are anticipated and addressed in this paper.

\section{INTRODUCTION}

Some economists from the Austrian school tend to criticize the Sexistence of the central banks and suggest their abolition and transition towards a free banking system. Nonetheless, the existence of the central banks is a state that apparently cannot be changed, at least in the near future. For this reason, suggestions of the central

\footnotetext{
*Tomáš Frömmel (tomas.frommel@vse.cz) is a Ph.D. student in the economics department at the University of Economics, Prague. 
banks' abolition cannot be taken seriously, since they are far away from current reality. Although it may be true that the economy would develop better without the central banking system, Austrian economists might come up with some more realistic suggestions of rules for central bank policy.

The aim of this paper is, therefore, to develop a non-distortionary monetary policy objective consistent with the Austrian business cycle theory. The central bank committed to such an objective should not lower permanently the market rate of interest below the natural level, and would not distort free-market system of relative prices and trigger artificial boom-bust cycles.

The introduction of a negative inflation target combined with the Taylor rule is suggested as a satisfactory policy objective, complying with requirements presented above. Since, in the Hayekian framework, the price level should fall as the natural output of the economy grows, monetary policy could be less activist compared to the current state of positive inflation rate targeting; relative prices would not be distorted by permanent injections of new money into the economy and the course of economic development could be smoothed under the proposed rule.

There have already been some suggestions that the price level should be allowed to fall in the growing economy (e.g. Hayek 1935, Friedman 1984, Selgin 1997, or Potužák 2016). Unlike these papers, this essay respects the fact that current central banks do not target money supply and rather use interest rates as their policy instrument. Therefore, we aim to propose a non-distortionary rule prescribing how the central bank might set its interest rates. For this reason, our suggestion might be more realistic compared to the other suggestions.

The structure of the paper is as follows. The first section briefly presents monetary policy rules and especially the inflation targeting regime and the Taylor rule. The second section presents criticism of the inflation targeting from the Austrian perspective. The next section suggests the introduction of a negative inflation target and explains advantages of this policy. The last section aims to anticipate possible criticisms of the suggested policy and tries to disprove them. 


\section{INFLATION TARGETING AND THE TAYLOR RULE}

Monetary policy rules are commonly seen as more convenient than discretionary policy (Sargent and Wallace 1975, Barro and Gordon 1983, or Svensson 1999). The main argument in favor of policy rules is the problem of time inconsistency of the central bank policy. A central bank committing itself to some policy rule should not adopt any policy that has not been declared in advance. Policy rules may thereby reduce entrepreneurs' uncertainty concerning future monetary policy conditions, and the central bank becomes more predictable.

Furthermore, if arguments of the Austrian business cycle theory critics (e.g. Tullock 1988, Cowen 1997, or Wagner 1999) were right, monetary policy rules should lead to gradual smoothing of the cyclical development of the economy. If the central bank adopted and publicly communicated some policy rule, monetary policy would become more transparent and entrepreneurs would be able to understand the consequences of central bank policies more easily. Then, they would not be fooled by the monetary authority and an artificial boom ${ }^{1}$ would not be triggered. To adopt a policy rule seems to be a suitable action since it limits the central bank's ability to increase the amount of money in the economy and hereby initiates artificial boom-bust cycles.

One of the most common monetary policy rules or regimes is inflation targeting, defined by Bernanke and Mishkin $(1997,97)$ as "the announcement of official target ranges for the inflation rate at one or more horizons and... explicit acknowledgement that low and stable inflation is the overriding goal of monetary policy." This regime of monetary policy is defended mostly for its high transparency and comprehensibility. A credible central bank may, by setting and publicly communicating its inflation target, simply

${ }^{1}$ The Austrian business cycle theory (Mises 1953, Hayek 1933 and 1935, or Garrison 2001) predicts that lowering the market rate of interest below its natural level and subsequent non-uniform inflow of new money into the economy leads to investment into more roundabout production processes. Since increased investments are not accompanied by increased voluntary savings, newly created structures cannot be finished in the future. The economic boom is not sustainable for this reason, and the recession is an unavoidable result that allows re-equalization between real savings and investments. 
control inflation expectations of agents in the economy and hereby control the inflation rate (Bernanke and Mishkin 1997). Furthermore, Svensson (1999) states that the inflation targeting regime helps to maintain low and stable inflation rate in the long run.

Taylor (1993) suggests a policy rule that allows the central bank to respond to the output gap and to the difference between the actual inflation rate and target for the inflation rate. The rule may be expressed by the following equation according to Mankiw's (2009) macroeconomics textbook: ${ }^{2}$

$$
\text { (1) } i_{t}=\rho+\pi_{t}+\theta_{\pi}\left(\pi_{t}-\pi^{T}\right)+\theta_{y}\left(y_{t}-y^{*}\right) \text {, }
$$

where $i$ denotes the central bank's nominal rate of interest, $\pi$ stands for the rate of inflation, $\pi^{T}$ is the central bank's target for the inflation rate (set as a positive number), $\left(y_{t}-y^{*}\right)$ expresses the percentage difference between current real output of the economy and its natural level, $\rho$ is the natural rate of interest, and parameters $\theta_{\pi}$ and $\theta_{Y}$ express responsiveness of the central bank to changes in the inflation rate and to the deviations of real output from its natural level. Parameters $\pi^{T}, \theta_{\pi}$ and $\theta_{Y}$ are set by the central bank. Money supply is endogenous under this rule.

The Taylor rule implies that if the rate of inflation is on the target and output does not deviate from its natural level, the central bank should set its nominal rate of interest equal to the nominal equilibrium rate of interest $\rho+\pi_{t}$. If the rate of inflation decreases below the inflation target, the central bank should decrease its nominal rate of interest and vice versa. ${ }^{3}$

Despite its several critics (e.g. Orphanides 2001, or Orphanides and Williams 2002), some version of the Taylor rule is used in models of new Keynesian economists (e.g. Clarida, Galí and Gertler 1998, or Svensson 2000a).

${ }^{2}$ Taylor (1993) assumed specific values of parameters $\rho, \pi^{T}, \theta_{\pi}$ and $\theta_{\gamma}$. Mankiw's (2009) equation is written without any assumptions for parameters and variables.

${ }^{3}$ A sufficiently strong decrease in the central bank's rate of interest pushes the real rate of interest downwards, below the natural level. This stimulates investments and consumption and increases the rate of inflation, which is hereby stabilized at its target. 


\section{INFLATION TARGETING: AN AUSTRIAN PERSPECTIVE}

Let us now assess the policy of inflation targeting from an Austrian perspective. The first problem may arise with the definition of inflation. While Austrian economists usually define inflation as an increase in the quantity of money in the circulation, mainstream economists usually speak of an increase in the aggregate price level (Bagus 2003). For purposes of this paper, let us accept the mainstream definition; inflation means a rising price level and may be measured by the consumer price index or by the GDP deflator.

Another, more serious, problem arises with targeting the positive inflation rate in the growing or stationary economy. While all central banks targeting inflation have positive inflation targets, Hayek (1928) suggests that if the quantity of money is held constant, prices must fall if the output rises and vice versa.

Hayek (1935) further argues that in the growing economy, the equality of the natural rate of interest and the market rate of interest is feasible only in case of the falling price level; price level should not be stabilized in the growing economy., ${ }^{4,5}$ If prices are intended to rise or remain stable in such an economy, the central bank must permanently increase the amount of money in circulation, and it thereby creates permanent pressure for the reduction of the market rate of interest below its natural level. ${ }^{6}$

This may be simply shown using the quantity theory of money and the equation of exchange:

(2) $M(t) \cdot V(t)=P(t) \cdot Y(t)$,

\footnotetext{
${ }^{4}$ Wicksell (1936) argues that the market rate of interest is equal to its natural level in case of stabilized price level. Hayek (1935) objects that this holds only in the stationary economy. Further discussion on this issue may be found in Potužák (2018).

${ }^{5}$ White (1999) points out that Hayek (1976) not criticizing price level stabilization is not consistent with his previous works. Komrska and Hudík (2016) reject this alleged inconsistency.

${ }^{6}$ This holds regardless whether the central banks control interest rates or the money supply. An attempt to stabilize the price level in the growing economy leads to an increase in the money supply and to a decrease in the rate of interest below its natural level.
} 
where $M$ expresses the money supply, $V$ velocity of circulation of money, $P$ aggregate price level and $Y$ real output. The expression $M V$ on the right side of the equation 2 may be called nominal income of the economy.

Equation 2 implies that in case of a stable velocity of money and a stable money supply, nominal income is stable as well; then, if real output rises, the price level must fall. A permanent increase in the price level in an economy with growing natural output unambiguously implies the necessity of a permanent increase in the money supply or velocity. Targeting a positive inflation rate in the economy with growing or stationary natural output necessarily implies permanent pressure for the reduction of the market rate of interest below its natural level, which according to the Austrian business cycle theory, distorts the free market system of relative prices and triggers an artificial boom. Potužák (2018), therefore, shows that inflation targeting (or price level stabilization) is not a suitable policy in the economy with growing natural output; price level may be stabilized only in a stationary economy.

Furthermore, inflation targeting leads to the distortions in the free market system of relative prices (Cochran 2004). An increase in the price level due to an increase in the amount of money in circulation is never uniform; some prices rise and some may even fall when the central bank injects new money into the economy (Mises 1953). Selgin (1997) describes a case of a decrease in only one individual price due to a positive shift in technology while all the other prices remain unchanged. In such case, aggregate price level slightly decreases, and the central bank needs to increase the money supply to stabilize it. Thus, after a decrease in only one individual price, the central bank aiming to stabilize the price level changes all the prices in the economy. Selgin (1999) states that even Hayek realized that attempts to stabilize the price level if real output rises lead to serious dislocations of relative prices.

The last objection deals with the central bank's alleged ability to simply control inflation expectations in the economy. This might be true; nevertheless, Murphy (2005) proposes that entrepreneurs need not care about all prices in the economy or about the aggregate price level. What matters in entrepreneurs' decision-making are expectations about only a small set of market prices; entrepreneurs need to know only prices of their inputs and outputs. Since an 
increase in prices after monetary expansion is never uniform (Mises 1953), inflation expectations are different from expectations of individual price movements. All individual prices may change even in case of price level stability; hence, entrepreneurs may expect a change in a small set of prices even in case of a stabilized price level. Furthermore, some individual prices may decrease even in the case of an increasing price level. The presumed advantage of the inflation targeting regime might be hereby partly disproved from an Austrian perspective since the central bank does not possess the ability to control individual-price expectations, but only price-level expectations or inflation expectations. ${ }^{7}$

To sum up this section, it seems that inflation targeting suffers from several serious objections and, from an Austrian point of view, should not be evaluated as a suitable regime of the central bank policy in the growing economy. In the next section, we will introduce a rule that might be more convenient from the Austrian perspective.

\section{SUGGESTION OF THE NEGATIVE INFLATION TARGET}

There have already been some attempts to suggest a monetary policy rule that would not initiate boom-bust cycles in the growing economy. Hayek (1935) proposes that the central bank should not stabilize the price level, but rather money stream defined by the total nominal spending in the economy. Potužák (2016) explains that only keeping the money stream MV constant protects the economy against adverse effects of shocks to the velocity of money circulation that are similar to the effect of shocks to the money supply. Under Hayek's (1935) rule, ${ }^{8}$ money supply changes only in case of velocity changes; the central bank compensates changes in velocity of money circulation by opposite changes in the amount of money in the economy. Under such a rule, the price level would fall in the economy with growing natural output, which is consistent with the Austrian view presented in the previous section.

\footnotetext{
${ }^{7}$ Inflation targeting might be probably problematic from some parts of mainstream economics (i.e. Lucas 1972) as well since it targets something that no single agent in the economy uses as his benchmark.
}

${ }^{8}$ Potužák (2016) uses the term 'Hayek MV-rule.' 
Nevertheless, currently central banks usually do not control the money supply but set nominal interest rates to keep the money growth within a certain interval and to fulfill their objectives. For this reason, Hayek's proposal is not further considered as a suitable rule, but the suggestion of stabilizing money stream MV will be preserved.

Some economists (e.g. Bean 1983, Hall and Mankiw 1994, West 1994, or McCallum and Nelson 1999) suggest nominal income targeting as an optimal monetary policy regime. Nominal gross domestic product would grow at a constant rate equal to the sum of the long-run average rate of growth of real output and targeted inflation rate. Nonetheless, such a policy is not significantly different from the inflation targeting. If nominal income growth is targeted, the right side of equation 2 is targeted to rise permanently. Then, the left side must grow at a stable growth rate as well, which means a permanent injection of new money into circulation. For this reason, nominal income targeting cannot be recommended as a suitable policy, since it suffers from the same problems as the inflation targeting.

As was already explained in the previous section, the Hayekian framework predicts that the aggregate price level must fall in the economy with growing natural output. Hence, introduction of the negative inflation target is suggested. The quantity theory of money and the equation of exchange is used to derive this negative inflation target. Equation 2 may be rewritten using the growth rates of all variables, obtaining the following equation:

$$
\text { (3) } \frac{\dot{M}(t)}{M(t)}+\frac{\dot{V}(t)}{V(t)}=\frac{\dot{P}(t)}{P(t)}+\frac{\dot{Y}(t)}{Y(t)} \text {. }
$$

A constant money stream $M V$ is desired for the reasons explained above. Equality of the growth rate of the economy with the growth rate of potential output is assumed in the long run:

(4) $\frac{\dot{Y}(t)}{Y(t)}=\frac{\dot{Y}^{*}(t)}{Y^{*}(t)}$

Hence, conclusions of Hayek (1928, 1935) combined with equations 3 and 4 imply the following formula for the optimal inflation target: 
(5) $\pi^{T}(t)=-\frac{\dot{Y}^{*}(t)}{Y^{*}(t)}$

implying that in the Hayekian framework, the growth rate of the price level should be equal to the opposite to the growth rate of the potential output of the economy. The central bank could still use the Taylor rule and only use the equation 5 to set its optimal inflation target. Since the growth rate of the economy is roughly constant in the long run on the balanced-growth path (Barro and Sala-i-Martin 2004), target for inflation should be constant over time as well in such an economy. ${ }^{9}$

Such a monetary policy regime could be acceptable for advocates of the inflation targeting (Bernanke and Mishkin 1997, or Svensson 1999) since their arguments in favor of the regime of inflation targeting might hold regardless whether the target is positive or negative. The suggestion of a negative inflation target incorporates a desired high level of transparency, trustworthiness and predictability of the central bank policy; by publicly announcing its negative inflation target, the central bank might reduce uncertainty concerning future monetary policy conditions and hereby control inflation expectations of entrepreneurs. Thus, from this perspective, inflation targeting with the positive target might not be more advantageous compared to the suggested negative inflation target policy. ${ }^{10}$

Nonetheless, negative inflation target policy could be more suitable than the inflation targeting with the positive target. Since,

\footnotetext{
${ }_{9}^{9}$ Campbell and Mankiw (1987) argue that an economic development has a stochastic trend and, thus, a growth rate of the economy is not constant over time. If this were true, the inflation target should be set as a long-term average growth rate of the economy and should be held constant for a longer time period. It would mean that monetary policy would not be completely neutral, since changes in the growth rate of the economy could cause deviations of the central bank's inflation target from the optimal inflation target prescribed by the equation (4), but the central bank could simply control inflation expectations.

${ }^{10}$ Nonetheless, inflation targeting proponents (Bernanke and Mishkin 1997, or Svensson 1999) broadly defend positive inflation targets. Our suggestion of negative inflation target policy would probably be criticized by them, even though the central bank would remain transparent and predictable. This objection will be discussed in the fourth section.
} 
according to Hayek, the aggregate price level should gradually decrease in the economy that is going through technology-induced growth, monetary authority need not be so activist when targeting the negative inflation rate. Positive inflation rate in the economy with growing natural output must always be induced by the central bank injecting new money into the economy; on the contrary, negative inflation may be achieved per se, without any monetary authority actions.

If the central bank accepted negative inflation target policy, adjustments of the interest rate and money supply would not be needed so often and the free-market system of relative prices should be distorted less compared to targeting the positive inflation rate. Since the central bank would not permanently lower the money rate of interest below its natural level, monetary policy would not be excessively expansionary and would not initiate artificial boom and bust cycles so often. Output of the economy would be stabilized around its potential level and the course of the economic development would be smoothed.

Furthermore, since the central bank would not intervene permanently in the money markets, a free market system of relative prices would not be artificially distorted. Entrepreneurs might be able to form expectations and predictions of their prices more easily and more accurately than in case of the positive inflation target since prices would be affected only by market forces and fundamentals and not by monetary authorities (Murphy 2005).

Finally, introduction of a negative inflation target might not mean a large change in current central bank policies. Central banks setting a negative inflation target could still use some kind of the Taylor rule; the suggestion of a negative inflation target means only a change in one parameter of the monetary policy rule determined by the central bank.

\section{POSSIBLE CRITICISMS OF A NEGATIVE INFLATION TARGET POLICY}

Besides previously discussed advantages of the negative inflation target, there might be some criticisms of the suggested policy rule. This section aims to anticipate and partly disprove them. 
Firstly, the suggested policy with a negative inflation target could not ensure absolute soundness of money. The central bank would have to intervene in credit markets in case of changes in the velocity of money circulation. A decrease in velocity should be accommodated by an increase in the money supply that would keep the money stream $M V$ constant (Hayek 1935). Nevertheless, since injections of new money into the economy are not uniform and it is not ensured that new money enter exactly to the sectors with decreased velocity, free-market system of relative prices may be distorted by an inflow of new money. This monetary accommodation is, however, desirable since otherwise the economy would suffer from stronger deflation than implied by equation 5 .

Moreover, the central bank would have to intervene during the business cycle since real output of the economy equals to the potential output only in the long run, and the same holds for the inflation rate and inflation target. In the short run, since the economy is hit by supply and demand shock and goes through cyclical fluctuations, the central bank committed to the negative inflation target policy would have to intervene by adjusting the rate of interest (and hence the money supply) to stabilize the inflation rate at its target and the output at its potential. If the economy is hit by a positive supply shock (i.e. due to a drop in commodity prices) and deflation deepens, the central bank, to comply with its negative inflation target, needs to lower its rate of interest to increase the amount of money in the economy. Such policy leads to a smaller decrease in the aggregate price level and the desired negative inflation rate target is met. ${ }^{11}$ Nonetheless, the increase in prices after a monetary expansion is not uniform and the free market system of relative prices is distorted by such an attempt to override a supply-driven price development. The Austrian business cycle theory predicts that an artificial boom might be triggered by such policy. Hence, the suggested policy might not work optimally during the recessions when the inflation rate decreases below its target, which is attainable only after monetary expansion. Hence,

\footnotetext{
${ }^{11}$ The other possible way to conduct monetary policy in such a situation would be not to react at all and to let prices freely adjust. We treat such policy as less suitable since the rate of inflation would not be stabilized at the target and the central bank would lose control over inflation expectations.
} 
the suggested policy might not be called non-distortionary, but rather less distortionary.

This criticism of inflation targeting, however, holds regardless of whether the inflation target is positive or negative. Nonetheless, Mises (1953) and Hayek $(1933,1935)$ claim that cyclical fluctuations of the economy are induced by overly expansionary policy of the monetary authority. The previous section concluded that a negative inflation target policy restricts interventions of the central bank in the credit markets and might lead to the business cycle smoothing. Then, the inflation rate should not deviate frequently from its targeted value and the frequency of central bank interventions should be lower compared to the positive inflation-target policy. From this perspective, the negative inflation target seems to be more appropriate than the positive target, although absolute neutrality of money would not be ensured.

Secondly, negative inflation target might be criticized by New Keynesians since they commonly prefer a positive inflation rate and there occurs a widespread fear from deflation (e.g. Akerlof, Dickens and Perry 1996, or Bernanke and Carey 1996). However, Borio and Filardo (2004a) distinguish three types of deflation: the good, the bad, and the ugly. Deflation implied by the proposed negative inflation target policy corresponds to the good one, caused by an increase in labor productivity and economic growth. Hence, there might be no reason for fear from this harmless deflation. Furthermore, Sargent and Wallace (1975) suggest that fully anticipated price changes should have no effect on the economic development. If the central bank with the negative inflation target were credible enough, there would be no unexpected deflation and no harmful effects on the economy. ${ }^{12,13}$

\footnotetext{
${ }^{12}$ Any differences between the actual and expected rate of inflation might be avoided to prevent the deflation spiral and potentially other adverse effects of deflation. For this reason, if the central bank decided to implement the suggested negative inflation target policy, it should be implemented by gradually decreasing the inflation target accompanied by transparent communication of the central bank, so that all people may build the decreased inflation target into their inflation expectations.

${ }^{13}$ Atkeson and Kehoe (2004) and Ryska (2017) showed empirically that there is no link between deflation and depression, except for the period of Great Depression. This may be another argument against fear from deflation.
} 
Another argument in favor of the positive inflation rate claims that even fully anticipated deflation may be harmful since it leads to a reduction in consumer spending; consumers expect further decrease in prices and postpone their purchases in order to buy cheaper in the future (Krugman 1998). Potužák (2015) rejects this argument since the optimal flow of consumption over time does not depend on a ratio of present and future prices of consumption goods. The intertemporal allocation of consumption is determined by the real rate of interest. If expected deflation leads to a decrease in nominal rate of interest, real interest rate remains unaffected and optimal flow of consumption remains unaffected as well. Hence, there is no reason to be afraid of spending postponement in case of fully expected deflation. ${ }^{14}$

Thirdly, the proposed policy might be criticized for the problem of the zero-lower bound on nominal interest rates. Many economists (e.g. Summers 1991, McCallum 2000, Reifschneider and Williams 2000, Svensson 2000b, or Eggersson and Woodford 2003) point out that nominal interest rates cannot fall below zero. In case of the inflation rate below the target, the Taylor rule implies the necessity of lowering the central bank's rate of interest. Because of the zero-lower bound, nominal interest rate could not be decreased below zero, which would increase real interest rate and the central bank would not be able to meet its inflation target. One might expect that the probability of the lower zero bound attainment would be increased in case of negative inflation target since equilibrium nominal interest rates would be closer to zero, compared with targeting the positive inflation rate.

Let us solve this issue. The Fisher equation expresses the following relation between the nominal and real rate of interest:

(6) $i(t)=r(t)+\pi(t)$,

where $i$ denotes the nominal interest rate, $r$ stands for the real interest rate and $\pi$ expresses the inflation rate. It is obvious that the negative inflation rate decreases the nominal interest rate compared to the positive target. Assuming that the inflation rate equals its target and real output is stabilized around its potential in the long

\footnotetext{
${ }^{14}$ Further discussion on this issue may be found in Kovanda and Komrska (2017).
} 
run, plugging equation 5 into equation 6 implies that under the negative inflation target policy, the nominal interest rate would be given (in the long run) by the difference between the real interest rate and the growth rate of potential output of the economy:

(7) $i(t)=r(t)-\frac{\dot{Y}^{*}(t)}{Y^{*}(t)}$.

It may be shown that the real rate of interest is higher than the growth rate of the real output if the economy is dynamically efficient (Romer 2006), hence, if the economy does not over-accumulate capital. In such an economy, the nominal interest rate is positive in the long run (Potužák 2016). Hence, even if the central bank targeted negative inflation rate, nominal interest rate would remain positive in the long run. ${ }^{15}$

A zero lower bound might be hit in the short run since the inflation rate may fall below the target and a negative output gap may occur during the business cycle. In such a case, the Taylor rule prescribes that the central bank should lower the nominal interest rate. Since the nominal interest rate would be close to zero in the long run, there would be only limited scope for lowering the interest rates and the zero lower bound might be hit. Nonetheless, we have shown that the course of the business cycle might be smoothed under the negative inflation target policy, hence, the zero bound on nominal interest rates should not represent a serious threat under the proposed policy rule. Furthermore, since the path of economic development should be smoothed under the proposed policy, the probability of the zero-lower bound hit should be even lower than in the case of positive inflation target. The proposed negative inflation target policy might be superior to the current policies with positive inflation targets. ${ }^{16}$

\footnotetext{
${ }^{15}$ Nominal interest rate would definitely be closer to zero than in the case of positive inflation target.

${ }^{16}$ Furthermore, Borio and Filardo (2004b) examining 14 economies in the $19^{\text {th }}$ century conclude that the zero bound was never hit when the economy experienced sound deflation driven by technological progress and economic growth. This empirical result might support our theoretical conclusions, although there were no central banks in most of countries in the $19^{\text {th }}$ century, while our suggestion of negative inflation target still counts with a central bank that actively sets interest rates.
} 
Finally, New Keynesian economists (e.g. Summers 1991, Akerlof, Dickens and Perry 1996, or DeLong and Sims 1999) claim that a moderate positive inflation rate permits maximum employment and output growth in the long run because of the downward nominal-wage rigidities. For this reason, Ball (2013) even argues for an increase in inflation targets. Deflation might lead to higher than natural growth in real wages, which would increase involuntary unemployment. Nevertheless, the question is whether a decreasing profile of nominal wages would be necessary under the suggested policy. As the economy goes through the technology-induced growth, real wages grow because of the growing productivity of labor. Nominal wages might be kept constant and decreasing price level would lead to desired increase in real wages.

Let us examine this issue mathematically. Nominal wage $w_{N}$ is defined as a product of the real wage $w_{R}$ and the price level $P$ :

(8) $w_{N}(t)=w_{R}(t) \cdot P(t)$.

Then, the growth rate of the nominal wage may be expressed by the following equation:

(9) $\frac{w_{N}(t)}{w_{N}(t)}=\frac{\dot{w}_{R}(t)}{w_{R}(t)}+\pi(t)$.

Neoclassical growth models ${ }^{17}$ predict that in the economy on the balanced growth path (steady state), the growth rate of the real wage is given by the technology growth $g$. Furthermore, equation 5 expresses the idea that the growth rate of the price level under the suggested negative inflation target policy equals the opposite of the growth rate of the potential output. Neoclassical growth models predict that this growth rate is given by the sum of the population growth $n$ and the technology growth $g$. By plugging these growth rates into equation 9, we obtain the following formula for the growth rate of the nominal wage under the suggested policy:

$$
\text { (10) } \frac{\dot{w}_{N}(t)}{w_{N}(t)}=g-(n+g)=-n \text {. }
$$

\footnotetext{
${ }^{17}$ Neoclassical growth models are explained in Barro and Sala-i-Martin (2004) or Romer (2006).
} 
We have expressed that the nominal wage growth rate would be given by the opposite of the population growth rate. ${ }^{18}$ Hence, downward rigidity of nominal wages constitutes a serious objection against the suggested negative inflation target policy if this policy were used in countries with positive population growth. In such countries with downward rigidities of nominal wages, our suggestion would lead to higher than natural growth in real wages, which would increase involuntary unemployment.

Nevertheless, Hayek (1976), Selgin (1997) and de Soto (2012) state that rigidities in nominal wages may be strengthened by the inflationary monetary policy. If real wages are rising due to technological progress and the central bank targets positive inflation rate, nominal wages must rise by a higher growth rate than the price level. This creates an environment that limits downward flexibility of nominal wages. In an environment of a stable and expected decrease in the price level, rigidities in nominal wages could be at least partly eliminated since employees could be even willing to accept a moderate decrease in their nominal wages implied by equation 10 and a falling price level would lead to an increase in their real wages.

\section{CONCLUDING REMARKS}

This paper aimed to propose an objective for the central bank policy consistent with the Austrian business cycle theory. The research was motivated by the fact that many Austrian economists suggest a banking system without the central bank. Nevertheless, the existence of the central banks probably cannot be changed. Hence, Austrian economists might aim to find a non-distortionary rule for the monetary policy.

Since the price level should fall in the economy with growing natural output in the Hayekian framework, a positive inflation target is achievable only if the central bank regularly increases the amount of money in circulation. This policy is criticized from an Austrian perspective since increasing money supply pushes the money rate of interest below its natural level hereby initiates an artificial boom-bust cycle.

\footnotetext{
${ }^{18}$ Potužák (2015) comes to the same conclusion.
} 
Introduction of a negative inflation target was suggested in this paper. Since a constant money stream is desired from the Austrian perspective, we proposed inflation targeting with the target set as the opposite number to the growth rate of the economy.

Such a policy should be superior to the positive inflation rate target since it reduces activism of the monetary authority and smooths economic development. Furthermore, all advantages of the positive inflation targeting might be kept. Possible criticisms of the suggested policy rule were anticipated and aimed to disprove, although it is not a completely non-distortionary policy.

In our view, the main challenge for future research lies in integrating the Austrian theory of capital and business cycle into the DSGE models that are one of the building blocks of modern macroeconomics. Development of the economy under the suggested negative inflation target policy could be simulated in such framework, which could help to further disprove possible criticisms of our suggestion.

\section{REFERENCES}

Akerlof, George A., William T. Dickens, and George L. Perry. 1996. "The Macroeconomics of Low Inflation." Brookings Papers on Economic Activity 1996, no. 1: 1-59.

Atkeson, Andrew, and Patrick J. Kehoe. 2004. “Deflation and Depression: Is There an Empirical Link?" American Economic Review 94, no. 2: 99-103.

Bagus, Philipp. 2003. “Deflation: When Austrians Become Interventionists.” Quarterly Journal of Austrian Economics 6, no. 4: 19-35.

Ball, Laurence M. 2013. “The Case for Four Percent Inflation.” Central Bank Review 13, no. 2: 17-31.

Barro, Robert J., and David B. Gordon. 1983. "Rules, Discretion and Reputation in a Model of Monetary Policy." Journal of Monetary Economics 12, no. 1: 101-21.

Barro, Robert J., and Xavier Sala-i-Martin. 2004. Economic Growth. 2d ed. Cambridge: MIT Press.

Bean, Charles R. 1983. "Targeting Nominal Income: An Appraisal." Economic Journal 93, no. 372: 806-819. 
Bernanke, Ben S., and Kevin Carey. 1996. "Nominal Wage Stickiness and Aggregate Supply in the Great Depression." Quarterly Journal of Economics 111, no. 3: 853-83.

Bernanke, Ben S., and Frederic S. Mishkin. 1997. "Inflation Targeting: A New Framework for Monetary Policy?" Journal of Economic Perspectives 11, no. 2: 97-116.

Borio, Claudio, and Andrew J. Filardo. 2004a. "Back to the Future? Assessing the Deflation Record." BIS Working Paper No. 10329.

_ 2004b. "Looking Back at the International Deflation Record." North American Journal of Economics and Finance 15, no. 3: 287-311.

Campbell, John Y., and Gregory N. Mankiw. 1987. "Are Output Fluctuations Transitory?" Quarterly Journal of Economics 102, no. 4: 857-80.

Clarida, Richard, Jordi Galí, and Marc Gertler. 1998. “Monetary Policy Rules in Practice: Some International Evidence." European Economic Review 42, no. 6: 1033-67.

Cochran, John P. 2004. "Capital, Monetary Calculation, And The Trade Cycle: The Importance Of Sound Money." Quarterly Journal of Austrian Economics 7, no. 1: 17-25.

Cowen, Tyler. 1997. Risk and Business Cycles: New and Old Austrian Perspectives. London: Routledge.

DeLong, J. Bradford, and Christopher A. Sims. 1999. "Should We Fear Deflation?" Brookings Papers on Economic Activity 1999, no. 1: 225-52.

De Soto, Jesus H. 2012. Money, Bank Credit, and Economic Cycles. Auburn, Ala.: Ludwig von Mises Institute.

Eggertsson, Gauti B., and Michael Woodford. 2003. "The Zero Bound on Interest Rates and Optimal Monetary Policy." Brookings Papers on Economic Activity 2003, no. 1: 139-211.

Garrison, Roger W. 2001. Time and Money: The Macroeconomics of Capital Structure. London and New York: Routledge.

Friedman, Milton. 1984. "Monetary Policy for the 1980s." In To Promote Prosperity: U.S. Domestic Policy in the Mid-1980s., ed. John H. Moore. Stanford: Hoover Institution Press. 
Hall, Robert E., and Gregory N. Mankiw. 1994. "Nominal Income Targeting." NBER Working Paper No. 4439.

Hayek, Friedrich A. [1928] 1999. "Intertemporal Price Equilibrium and Movements in the Value of Money." Pp. 186-227 in Good Money. Part I, The New World, ed. Friedrich A. Hayek and Stephen Kresge. Chicago: University of Chicago.

—_. [1931] 1935. Prices and Production. 2d ed. New York: Augustus M. Kelly.

- 1933. Monetary Theory and the Trade Cycle. London: Jonathan Cape.

—. 1976. Denationalisation of Money. London: Institute of Economic Affairs.

Komrska, Martin, Hudík, Marek. 2016. “Hayek's Monetary Theory and Policy: A Note on Alleged Inconsistency." Review of Austrian Economics 29, no. 1: 85-92.

Kovanda, Lukáš, Komrska, Martin. 2017. “Deflace, Odklad Spotřeby a Hospodářské Krize: Rétorika Centrálních Bank vs. Ekonomická Literatura." Politická Ekonomie 65, no. 3: 351-69.

Krugman, Paul R. 1998. “It's Baaack: Japan's Slump and the Return of the Liquidity Trap." Brookings Papers on Economic Activity 1998, no. 2: 137-205.

Lucas, Robert. 1972. "Expectations and the Neutrality of Money." Journal of Economic Theory 4, no. 4: 103-24.

Mankiw, Gregory N. 2009. Macroeconomics. $7^{\text {th }}$ ed. New York: Worth.

McCallum, Bennett T., and Edward Nelson. 1999. "Nominal Income Targeting in an Open-Economy Stabilizing Model." Journal of Monetary Economics 43, no. 3: 553-78.

McCallum, Bennett T. 2000. “Theoretical Analysis Regarding a Zero Lower Bound on Nominal Interest Rates." Journal of Money, Credit and Banking 32, no. 4: 870-904.

Mises, Ludwig. [1912] 1953. Theory of Money and Credit. New Haven: Yale University Press.

Murphy, Robert. 2005. “The Rational Expectations Objection to Austrian Business Cycle Theory: Prisoner's Dilemma or Noisy Signal?" Working paper. Available at https://www.researchgate.net/publication/ 
228774555_The_Rational_Expectations_Objection_to_Austrian_ Business_Cycle_Theory_Prisoner's_Dilemma_or_Noisy_Signal.

Orphanides, Athanasios. 2001. "Monetary Policy Rules Based on Real-Time Data." American Economic Review 91, no. 4: 964-85.

Orphanides, Athanasios, and John C. Williams. 2002. "Robust Monetary Policy Rules with Unknown Natural Rates." Brookings Papers on Economic Activity 2002, no. 2: 63-146.

Potužák, Pavel. 2015. Capital and the Monetary Business Cycle Theory: Essays on the Austrian Theory of Capital, Interest, and Business Cycle. Dissertation thesis. Prague: University of Economics.

—_ 2016. “Hayek MV-rule." Working paper. Available at https://papers. ssrn.com/sol3/papers.cfm?abstract_id=2857719.

—_ 2018. "Price Level Stabilization: Hayek contra Mainstream Economics." Prague Economic Papers 27, no. 4: 449-78.

Reifschneider, David, Williams, John C. 2000. “Three Lessons for Monetary Policy in a Low-Inflation Era." Journal of Money, Credit and Banking 32, no. 4: 936-66.

Romer, David. 2006. Advanced Macroeconomics. 3d ed. Boston: Irwin/ McGraw-Hill.

Ryska, Pavel. 2017. “Deflation and Economic Growth: The Great Depression as the Great Outlier." Quarterly Journal of Austrian Economics 20, no. 2: 113-45.

Sargent, Thomas J., and Neil Wallace. 1975. "'Rational' Expectations, the Optimal Monetary Instrument, and the Optimal Money Supply Rule." Journal of Political Economy 83, no. 2: 241-54.

Selgin, George A. 1997. Less Than Zero: The Case for a Falling Price Level in a Growing Economy. London: The Institute of Economic Affairs.

—_. 1999. "Hayek versus Keynes on How the Price Level Ought to Behave." History of Political Economy 31, no. 4: 699-721.

Summers, Lawrence. 1991. “Panel Discussion: Price Stability: How Should Long-Term Monetary Policy Be Determined?" Journal of Money, Credit and Banking 23, no. 3: 625-31. 
Svensson, Lars E. O. 1999. "Inflation Targeting as a Monetary Policy Rule." Journal of Monetary Economics 43, no. 3: 607-54.

_ 2000a. "Open-Economy Inflation Targeting." Journal of International Economics 50, no. 1: 155-83.

— . 2000b. “The Zero Bound in an Open Economy: A Foolproof Way of Escaping from a Liquidity Trap." NBER Working Paper No. 7957.

Taylor, John B. 1993. "Discretion versus policy rules in practice." Carnegie-Rochester Conference Series on Public Policy 39, no 1: 195-214.

Tullock, Gordon. 1988. “Why the Austrians Are Wrong About Depressions.” The Review of Austrian Economics 2, no. 1: 73-78.

Wagner, Richard E. 1999. "Austrian Cycle Theory: Saving the Wheat while Discarding the Chaff." Review of Austrian Economics 12, no. 1: 65-80.

West, Kenneth D. 1986. “Targeting Nominal Income: A Note." Economic Journal 96, no. 384: 1077-83.

White, Lawrence H. 1999. “Hayek's Monetary Theory and Policy: A Critical Reconstruction." Journal of Money, Credit and Banking 31, no. 1: 109-20.

Wicksell, Knut. [1898] 1936. Interest and Prices. New York: Augustus M. Kelly. 